Revista ELectrónica de Investigación y EValuación Educativa
RELIEVE

25 YEARS

AÑOS
e-Journal of Educational Research,

Assessment and Evaluation

\title{
RELIEVE: 15 años de investigación y evaluación educativa
}

RELIEVE: 15 years of educational research and evaluation

\author{
Ruíz-Pérez, R. (D), \& Jiménez-Contreras, E. (D)
}

Universidad de Granada (España)

\begin{abstract}
Resumen
Objetivos: Análisis bibliométrico de los trabajos publicados por RELIEVE en los últimos 15 años; que se corresponden con los procesados por Emerging Sources Citation Index (ESCI), una nueva base de datos de Web of Science (WOS) que pretende corregir la deficiente cobertura de las revistas nacionales de algunos países. Método: Fuente de datos: 195 artículos de RELIEVE recogidas en ESCI. Análisis: Se analizaron las 7.408 referencias emitidas por los 195 trabajos. Igualmente se analizaron las 599 citas recibidas por la revista. Temáticas cubi ertas: se volcaron las Author-Keywords de los 195 trabajos en la herramienta de software VOSviewer. Resultados: las citas emitidas arrojan un promedio por trabajo de 38,19 $\pm 6,5$. Los autores y las revistas citadas son principalmente españolas; pero la proporción de revistas extranjeras de impacto es apreciable (40\%). Las citas recibidas por RELIEVE proceden casi de forma exclusiva de revistas españolas incluidas en WOS en la categoría Education and Educational Research. La lista de países e instituciones de los autores citantes está protagonizada también por España $(75,6 \%)$ y por las universidades de Valencia y Granada. Las citas vienen de artículos de investigación publicados en revistas españolas. Entre los temas de investigación que han ocupado las páginas de RELIEVE destacan los relativos a Educación Superior y PISA. Conclusiones: Las citas concedidas revelan un suficiente consumo de literatura científica internacional por parte de sus autores colaboradores. Por el contrario, las citas recibidas indican una fuerte atención a los temas locales en la investigación publicada, y como consecuencia esta investigación no es utilizada por investigadores de otros países. De momento, la presencia de RELIEVE en ESCIWOS aún no se ha traducido en una ruptura de su aislamiento nacional y en el inicio de su incorporación internacional en términos de impacto.
\end{abstract}

Palabras clave: Revista RELIEVE; Emerging Sources Citation Index; Investigación y Evaluación Educativa; Análisis de citas; Temas de investigación.

\begin{abstract}
Aims: To conduct a bibliometric analysis of papers published by the RELIEVE journal in the last 15 years. Considered papers were indexed by the Emerging Sources Citation Index (ESCI), which is a new Web of Science (WOS) database that aims to correct the poor coverage of national journals in some countries. Methods: Data source: 195 RELIEVE articles indexed according to the ESCI. Some 7,408 citations included in these 195 papers were analyzed. A total of 599 relevant citations recorded by the journal were also analyzed. Topics covered by the journal were also studied. For this purpose, author-keywords from the 195 papers were merged and analyzed using the VOSviewer software tool. Results: Papers included an average of $38.19 \pm 6.5$ citations. The authors and journals cited were mainly Spanish but a significant proportion of foreign impact journals $(40 \%)$ were also found. The references cited in RELIEVE came almost exclusively from Spanish journals included in WOS in the education and educational research categories. The majority of published papers also came from Spanish institutions (75.6\%), particularly the universities of Valencia and Granada. Most citations came from research papers published in Spanish journals. Amongst the research topics to have occupied the pages of RELIEVE, those related to higher education and PISA most stood out. Conclusions: The citations identified reveal appropriate consumption of international scientific literature by the publishing authors. However, these citations also highlighted a strong focus in published research on local issues and, as a consequence, this research is not highly considered by researchers from other countries. At the moment, RELIEVE's presence in ESCI-WOS has not yet been translated into gains regarding reduced research isolation and has failed to mobilize its international incorporation in terms of a more global impact.
\end{abstract}

Keywords: Relieve journal; Emerging Sources Citation Index; education and educational research; citation analysis; research issues.

\begin{tabular}{ll|l|r|} 
Received/Recibido 2020 November 9 & Accepted /Aprobado 2020 November 31 & Published/Publicado 2020 December 8 \\
\hline
\end{tabular}

Corresponding author / Autor de contacto: Ruiz-Pérez, R. University of Granada, School of Communication and

Documentation (Campus Universitario “La Cartuja” s/n, 10871- Granada, Spain) - rruiz@ugr.es 
In recent years, the number of scientific journals circulating worldwide has amounted to the publication of around 100,000 original journals. At the time of conducting this study, a targeted search in "Ulrichsweb: Global Serials Directory" using the search algorithm: Status $=(" A c t i v e ")$ Serial Type $=(" J o u r n a l ")$ Content Type $=("$ Academic / Scholarly") Key Feature $=$ (+"Referenced / Peer-reviewed"), resulted in the identification of 85,179 titles. These relate to all knowledge areas and come under any access type, print run, format and publication frequency. The aforementioned directory is considered to be a reliable and credible international source. It counts on a rigorous system for selecting and analyzing periodicals publications, whilst also providing monthly update reports. Thus, we can confirm that, according to the number of circulating titles available for almost all aspects of modern science, scientific journals are the main vehicle for knowledge diffusion.

In addition to this main role as a means of scientific communication, another aspect can also be added which is just as important. This refers to the use of journals as instruments for the evaluation of the scientific activity of authors, institutions and countries. In Spain, this use has proved to be especially decisive in relation to public policy regarding evaluation and incentives in the academic community. Such policies are developed, on the one hand, by the National Agency for Quality Evaluation and Accreditation (ANECA). ANECA is responsible for providing teacher accreditation. On the other hand, the National Commission for the Evaluation of Research Activity (CNEAI) grants additional research recognition every six years in Spain. Further, from the very beginning of the system in the nineties (Ruiz, Delgado and Jiménez, 2010), this system has been used in a highly selective rather than an indiscriminate way. Within the evaluation criteria, (CNEAI, 2019) greater weight has always been given to international journals of varying quality. This can be seen in the way these journals prevail in the Web of Science (WOS) database, under the signature of Clarivate Analytics (WOS, 2019) and, within this especially, through those classified with an impact factor (IF) and listed in the Journal Citation Reports (JCR) associated with a Science Citation Index (SCI) or Social Science Citation Index (SSCI).

It is, therefore, logical that interest in the editorial and scientific quality of these publications has grown within different sectors and perspectives. Above all, interest in overcoming the selection process for inclusion in the aforementioned WOS databases has notably increased in recent years. At the same time, this has set off a chain of events that have led to the proliferation of criteria and indices -indicators of bibliometric terminology- for the evaluation of such work. Amongst these tools, the most commonly used for indicating the quality and prestige of a publication is the citation count, pertaining to the number of times a work is cited, and the subsequent IF attributed to it.

Nonetheless, this indicator is not exempt from limitations. Seglen (1997) has previously warned of its deficiencies. This author identified, above all, the incomplete coverage of databases given this index (JCR-SCI and JCR-SSCI) and a general bias towards English language publications, principally those coming out of the United Kingdom and north America. Such bias occurs in detriment to other publications written in other languages. For national journals in the areas of social sciences and humanities, this problem can be even further accentuated. For these areas, the even worse coverage achieved causes bibliometric indices to lose efficacy. This leads to an important imbalance with regards to the natural sciences with have a more balanced representation (Torres-Salinas et al. 2010).

Now, differences in coverage have been corrected to a large extent in recent years by WOS, although gaps do remain. Such corrections particularly relate to countries such as Spain where international scientific potential, estimated here to be about $3.5 \%$ worldwide, did not previously correspond to a similar representation in national journals. This correction, despite not having taken place via direct JCR impact indices, has occurred through the incorporation of a significant 
number of titles to that denominated the Emerging Sources Citation Index (ESCI, 2020). This is a new product created by WOS which, most importantly, is included within the coverage of its core collection. In other words, the collection in which the emblematic SCI and SSCI citation indices are located.

As a consequence of all of this, it is important to focus on the current state of Spanish publications in the core collection of WOS. On the one hand, with regards to the presence of Spanish journals in JCR lists pertaining to IFs, the situation has experienced little variation over the last ten years, moving between 120-130. At the time of writing March 2020- a search of Spanish journals in the Master Journal list (MJL, 2020) produces a total of 129 titles, with 54 pertaining to JCR-SSCI and 75 corresponding to JCR-SCI. If we add the 64 articles currently found in the Arts \& Humanities Citation Index (A\&HCI), which is the third traditionally most important WOS index and is not associated with JCR, the figure increases to around 193 journals. If we consider that these three databases combined include 14,255 journals (SCI 9,043; SSCI 3,370; A\&HCI 1,843 ), Spain makes up $1.35 \%$ of research journals, this being a lower percentage than that pertaining to France with $1.8 \%$, and a long way away from the strong editorial showings made by Germany with $7 \%$, Holland with $8 \%$ and, of course, England with $24 \%$.

Nonetheless, as already indicated, from 2015 onwards these traditional indices that represent the most important international scientific literature from all knowledge areas were joined in WOS by the ESCI. This index applies to multidisciplinary content and had the essential aim of making up for the deficient coverage of some national journals (denominated regional according to WOS). This index indicates that, whilst the selected work does not yet benefit from worldrenowned prestige, it shows significant trends and scientific advances (emergent). It is, therefore, a candidate for inclusion in the emblematic citation indices (Testa, 2018) (WOS, 2020). If we examine the data, this product has brought about a huge turning point regarding WOS coverage. To the present day, ESCI covers 7,614 new journals from different countries (MJL, 2020). This has implied a $53 \%$ increase in WOS's core collection, rising from 14,255 to 21,869 journals. Of these 7,614 new journals, 572 are Spanish. This equates to $7.5 \%$ of all ESCI works and places it as the European country with the second highest number of contributions. Indeed, it is only exceeded by England with something more than 1500 journals. In conclusion, adding these 572 journals to the 193 included in the traditional indices gives Spain 765 journals, amounting to $3.5 \%$ of the entire main collection of WOS. This extent of coverage is clearly more akin to the country's scientific potential.

Without entering into too many details about the implications of ESCI (Ruiz and Jiménez, 2019), we will assume for the purpose of the present work that the state of ESCI journals responds to the status of journals under evaluation for accessing citation indices and those of JCR. This enables us to observe and measure different indicators through the data provided by the database. This means, amongst other issues, that we can follow the citation activity of covered journals and articles. Precisely, RELIEVE is one of the 60 plus education journals to have been incorporated into the ESCI. Further, following a check conducted on 05/03/2020, a total of 195 research works had been referenced and cited within the prestigious core collection of WOS. The aim of the present work is to analyze, through these references, a set of research indicators and profiles published by RELIEVE in the last 15 years. We will mainly focus on the citation activity of RELIEVE, considering both the citations included within the journal itself and those pertaining to RELIEVE mentioned in other journals. We will consider other aspects related with the collaborations and research topics approached by the journal.

\section{Method}

\section{Data source}


Complete references provided by WOS for the 195 articles registered at the time of the search provided the data source for the present study. These papers were published in RELIEVE between 2005-2019, with volumes 11-25 of the journal being considered. Different amounts of articles were published during different time periods, as follows: $2005-2010=70 ; 2011-2015=60 ; 2016-2019=$ 65. The search algorithm used was: Selec Database $=$ Web of Science Core Collection Basis Search $=$ Relieve or rev elec $^{*}$ inv $*$ eva* edu* $u^{*}$ Field tags $=$ Publication Name. The information produced in relation to each reference enabled us to obtain various indicators. Namely, these indicators pertained to whether the bibliographic type was sufficiently indicated, the title, authors, author affiliations, abstract, author keywords, document type, manuscript language, publication source, year, volume and issue. As an added value, WOS also permitted us to download included citations for every one of the 195 research works (citations produced by RELIEVE). These amounted to 7,408 produced citations. On the other hand, works cited at least once (cited research works pertaining to RELIEVE) were indicated. This was the case for some of the 195 research works published by RELIEVE (citations received by RELIEVE articles). This pertained to 599 cited works (produced) and 674 received citations (included self-citations and citations received from others).

\section{Data analysis}

In order to analyze the citations produced, an Excel spreadsheet was developed containing the 7,408 references (citations) produced by RELIEVE during the period of study. The data considered for each reference were: individual author(s) and/or responsible institution of the cited work; year of publication; cited journal, and; DOI of the work cited where relevant. These data enabled us to obtain the following indicators: average number of references for the period studied; citation curve over time; authors / institutions and journals cited.
For examination of the citations received by RELIEVE, we used the metrics provided by WOS. These metrics were applied to the 195 works recovered and obtained from the search described previously. Once these works were listed, they were accessed via the 'citing articles' link from the 'Create Citation Report' setting. This gave us access to the reference lists of 599 works cited by RELIEVE. Within this list, the 'Analyze Results' setting produced an output with the different indicators offered by WOS. For some of these indicators, it was decided to merge and handle the data in Excel. Data relating to the citation was analyzed according to the year of publication of the cited work, cited journals and knowledge areas to which the work belonged, cited authors, sign-off country and institutional affiliation, document type and language of the cited work.

For the analysis, the lines of research covered by RELIEVE during the study period were uncovered through the 'AuthorKeywords' included in the 195 works published by RELIEVE using the VOSviewer. This software tool allows us to construct and visualize bibliometric networks, in this case a map (cluster). This identifies co-occurrence of keywords and uncovers the core topics covered by the journal and its associations with the different research variables or approaches to have been considered.

\section{Results}

\section{Citations produced}

The 195 processed works, classified by WOS as 186 articles, 6 reviews and 3 book reviews, produced a total of 7,408 references. An average of $38.19 \pm 6.5$ citations was found per article. According to Figure 1, references produced by RELIEVE between 2005-2019 show a slight upward trend in their evolution, although with a small coefficient. Nonetheless, if numbers are compared to earlier years, it is seen that around 30 were produced relative to around 40 citations in later years. Thus, it is clear that the average number of citations has increased despite notable oscillations. 
Figure1. References per RELIEVE article

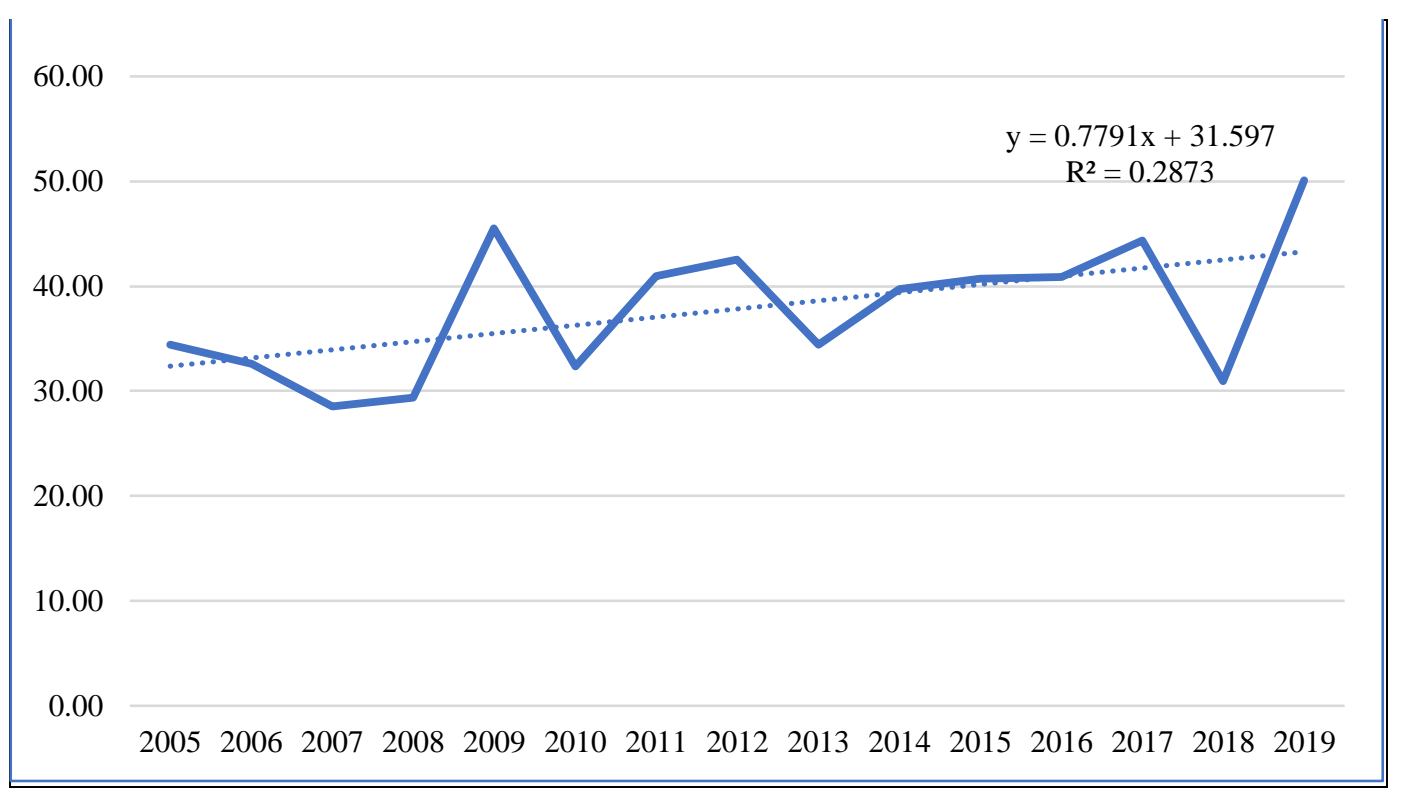

In another sense, when examining the year of publication of the cited source (RELIEVE articles) and the year of the cited references, we verified that the references were on average 7.5 years old 2005-2009, relative to 6.5 years old 2015-2019. This indicates that the references used in research are increasingly more contemporary or 'in-date'.
Figure 2 shows that both five-year periods evolve in a similar way. However, there is a significant difference, with the more recent articles pertaining to the 2015-2019 period giving publications in this period greater weight.

Figure 2. Curve relating to the antiquity of references cited in RELIEVE articles

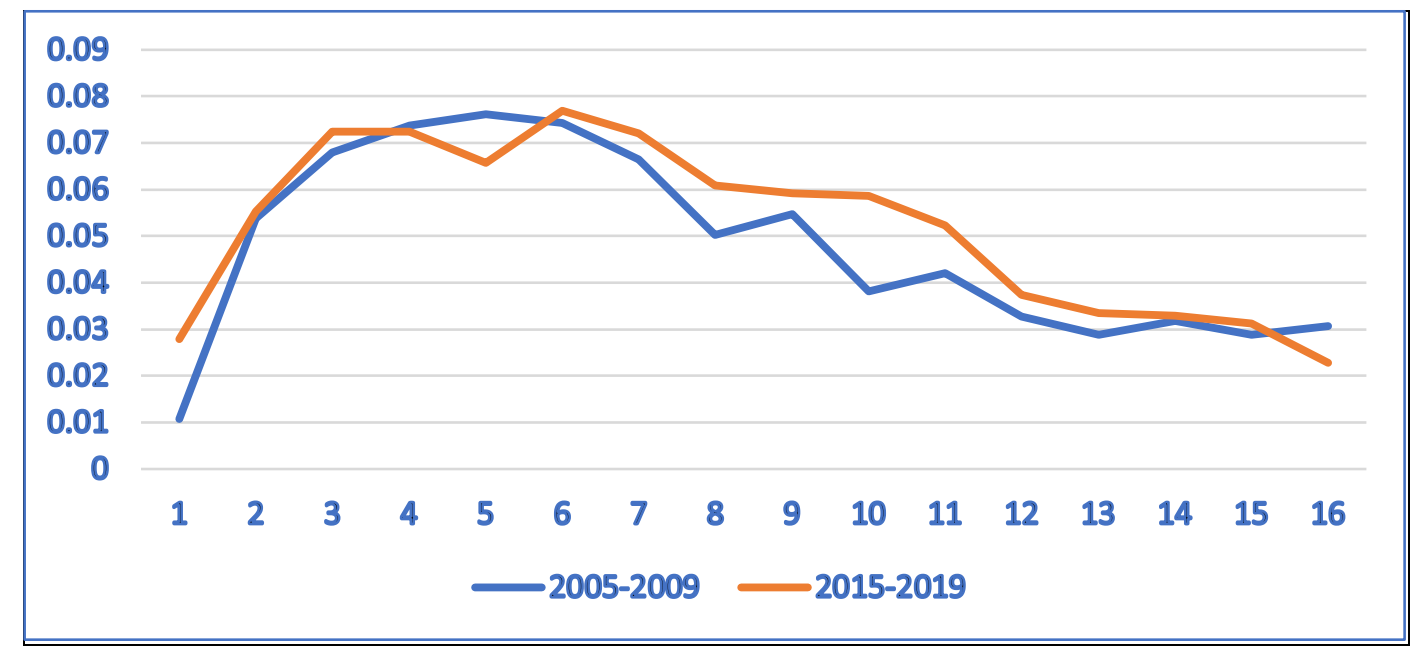

Another interesting aspect regarding the citation activity of RELIEVE relates to the leading authors and institutions cited for their published scientific literature in the journal. In relation to the authors, table 1 shows those whose works were most represented in the journal. Authors are divided according to Spanish nationals and foreign authors, with institutions being listed in cases when they were responsible for the cited document. 
Table 1. The authors most frequently cited in RELIEVE. 2005-2019

\begin{tabular}{lclclc}
\hline Nationals & Citations & Foreigner & Citations & Institutions & Citations \\
\hline Murillo F. J. & 30 & Marsh H. W. & 24 & PISA & 90 \\
Solano-Flores G. & 30 & Boud B. & 21 & OCDE & 87 \\
De Miguel Díaz M. & 29 & Biggs J. & 16 & Ministry of Education & 25 \\
Jornet J. & 29 & Carless D. & 14 & UNESCO & 17 \\
Aliaga Abad F.M. & 22 & Kember D. & 13 & CODICEN ANEP & 9 \\
Tejedor F. J. & 21 & Nicol D. & 13 & European Commission & 8 \\
Zabalza M. A. & 21 & Taras M. & 13 & Government of Andalusia & 8 \\
Gargallo B. & 17 & Backhoff E. & 11 & EURYDICE & 8 \\
Bandura A. & 16 & Gibbs G. & 11 & E. A. Development in SNE & 7 \\
Escudero T. & 16 & Goldstein H. & 11 & ANECA & 7 \\
Cabrera A. F. & 15 & Kember D. & 11 & Horizon Report & 7 \\
Ibarra M. S. & 15 & Schweinhart L. & 11 & & \\
Monereo C. & 15 & Zimmerman B. & 11 & & \\
Rodríguez Gómez G. & 15 & Brennan R. L. & 10 & & \\
Martínez Rizo F. & 15 & Brown S. & 10 & & \\
\hline
\end{tabular}

There is a predominance, although not excessive, of citations directed towards national authors. This indicates a greater concern for research on topics that are national and even local in nature. This state of affairs is reasonable given the importance of local factors and circumstances in educational research. Nonetheless, the data also reveal that the attention given to international institutions is highly important, especially that given to the OCDE. Indeed, the OCDE received three times as many citations as those received by the Spanish Ministry of
Education. With regards to the rest, although it is not technically an institution, the citations received by the so-called PISA reports were considered given their importance and the attention given to them by researchers. Indeed, if these reports did constitute an institution it would be the most cited institution of all.

With regards to the journals cited, those indicated in the present research are also covered by JCR and so the relevant quartile is presented (Table 2).

Table 2. Most cited journals by RELIEVE. 2005-2019

\begin{tabular}{|c|c|c|c|c|c|}
\hline Spanish journals & Citations & JCR & Foreign journals & Citations & JCR \\
\hline RELIEVE & 135 & & ASSESS EVAL HIGH EDU & 58 & Q1 \\
\hline REV EDUC & 135 & Q4 & STUD HIGH EDUC & 53 & Q1 \\
\hline RIE-REV INVESTIG EDU & 114 & & HIGH EDUC & 38 & Q1 \\
\hline PSICOTHEMA & 55 & Q2 & J EDUC PSYCHOL & 33 & Q1 \\
\hline REV IBEROAMERICANA E & 41 & & J EDUC MEAS & 29 & Q4 \\
\hline REV ESP PEDAGOG & 36 & Q4 & COMPUT EDUC & 28 & Q1 \\
\hline BORDON & 35 & & AM J EVAL & 27 & Q2 \\
\hline REV EDUC RES & 31 & & EVAL PROGRAM PLANN & 27 & Q3 \\
\hline EDUC XX1 & 30 & Q2 & AM EDUC RES J & 25 & Q1 \\
\hline REV ELECT INVESTIGAC & 24 & & EDUC PSYCHOL MEAS & 25 & Q2 \\
\hline COMUNICAR & 23 & Q1 & RES HIGH EDUC & 23 & Q2 \\
\hline INFANC APRENDIZ & 21 & & ED RES & 20 & Q2 \\
\hline AULA ABIERTA & 15 & & PSYCHOL BULL & 18 & Q1 \\
\hline REICE REV ELECT IBER & 15 & & PSYCHOMETRIKA & 17 & Q1 \\
\hline REV COMPLUT EDUC & 15 & & TEACH TEACH EDUC & 17 & Q1 \\
\hline \multirow[t]{4}{*}{ REV INTERUNIVERSIT } & 15 & & BRIT J EDUC TECHNOL & 16 & Q1 \\
\hline & & & SCH EFF SCH IMPROV & 16 & Q2 \\
\hline & & & ED MEASUREMENT & 15 & Q3 \\
\hline & & & COMPUT HUM BEHAV & 15 & Q1 \\
\hline Total citations & 740 & & & 500 & \\
\hline
\end{tabular}


A greater number of citations are directed towards Spanish journals relative to foreign journals, although these citations are distributed between fewer articles. This was the case even when RELIEVE itself was excluded. Logically, the readership of Spanish education journals is much smaller than that of overseas journals. Nonetheless, citations of Spanish texts on this specialty far exceed one hundred. Thus, is seems logical to arrive at the conclusion that many of these journals are used little by researchers who collaborate with RELIEVE. Despite this, given that the coverage achieved by RELIEVE targets research and evaluation, the absence of journals with profiles that are not in line with this coverage may be justified. Finally, it should be noted that the importance of psychology journals is noteworthy. These stand out in both the national and overseas list, with psychology constituting the only area to appear outside of education.

Nonetheless, with regards to the quota of cited foreign journals, it is important to underline that a reasonable coverage was achieved with around $40 \%$ being from abroad. This percentage is far from negligible given that we are dealing with the area of social sciences. Further, the majority are JCR journals in the first quartile (Q1) of the category pertaining to EDUCATION \& EDUCATIONAL RESEARCH, with notable penetration into the PSYCHOLOGY, EDUCATIONAL category, with the former being the main specialty for RELIEVE.

In order to complete this visual examination of cited journals, we have developed a network map (Figure 3). Naturally, RELIEVE is placed at the center of the map with the most influential Spanish journals placed next to it (regardless of the number of citations, table 2). These sources were the following: Revista de Educación [Journal of Education], RIE, Bordón [Journal of Pedagogy] and Educación XXI [Education $X X I]$. It serves to highlight the weight of citations given to theses. Whilst these are not journals, we have kept them in the network in order to emphasize the importance of doctoral works in research published by RELIEVE. Amongst the foreign journals included, those of Assessment Evaluation, Education Measurement and Higher Education most stand

out.

Figure 3. Network of journals cited in RELIEVE. 2005-2019

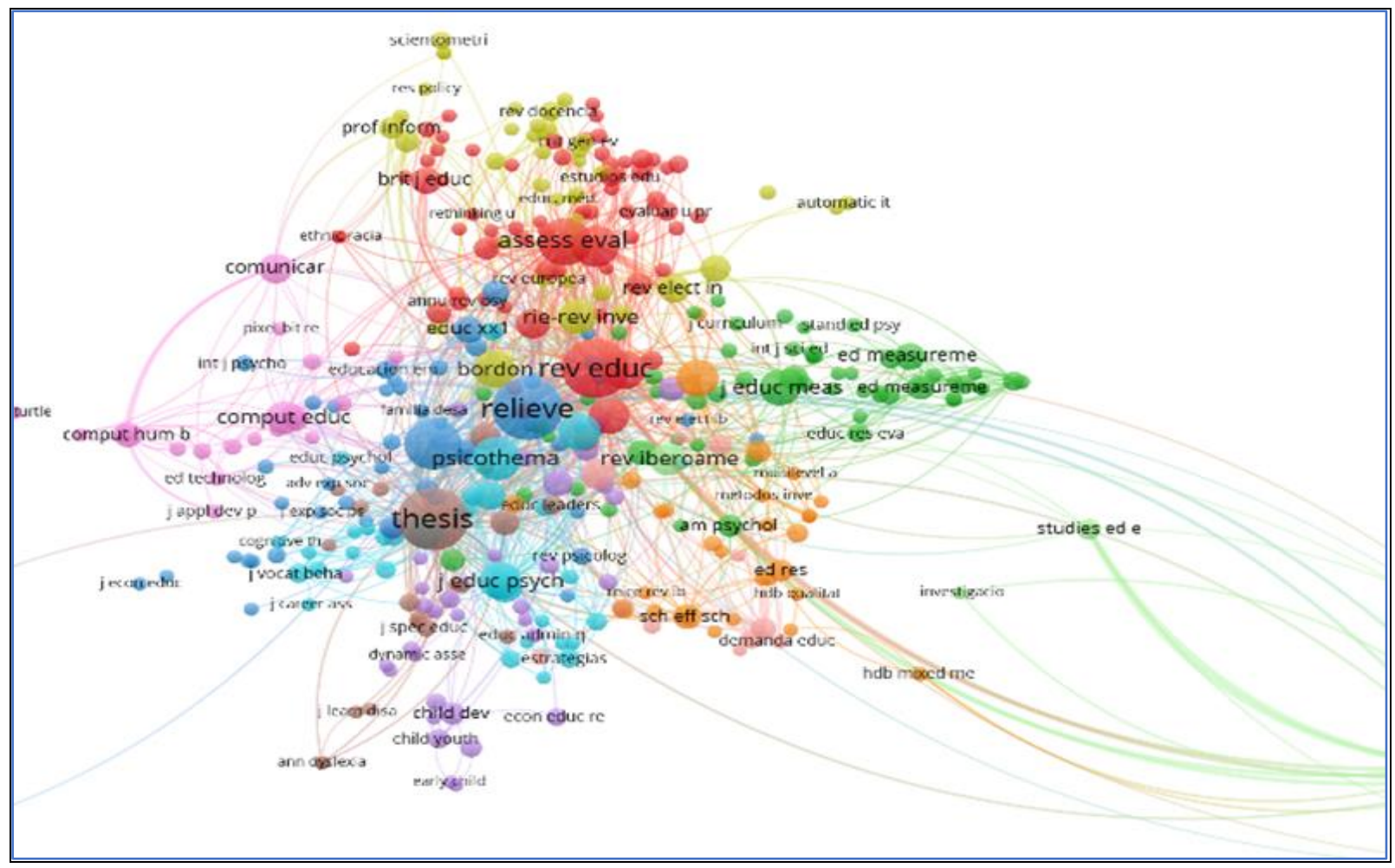


Amongst the journals that do not have a defined educational profile, Psicothema stands out. This is because it is found within the closest group to RELIEVE, being located in the same cluster. This leads us to think that, being a multidisciplinary psychology journal, works related to educational guidance published by this journal are being used. Finally, it serves to highlight that the main weight of publications in the journal Comunicar [Communicate] are linked to a more technological profile.

\section{Received citations}

We have already mentioned that 599 research works have cited, on at least one occasion, one or more of the 195 research texts published by RELIEVE and indexed according to the ESCI within the core collection of WOS. Concretely, of these 195 research works, 132 have received at least one citation. If we place texts in descending order according to the number of citations received, works with 15 or more citations take up only the first 9 positions in the list. Research works with 5 or more citations take up the next positions up until position 45 , and those with only 1 citation are found between the $91^{\text {st }}$ and $132^{\text {nd }}$ positions in the list. All of the above gives us the idea that there is an uneven distribution of citations across the articles published by RELIEVE. Table 3 presents the 10 most cited works during the study period, alongside the authors, year of publication and number of received citations.

Table 3. Most cited RELIEVE publications. 2005-2019

\begin{tabular}{|c|c|c|c|}
\hline Authors & Title & Year & Citations \\
\hline $\begin{array}{l}\text { Cabrera, L.; Bethencourt, J.; } \\
\text { Álvarez, P. et al. }\end{array}$ & The dropout problem in University Study & 2006 & 56 \\
\hline Area, M. & $\begin{array}{l}\text { The Information and Communication Technologies in the } \\
\text { school system. A review of the research lines }\end{array}$ & 2005 & 50 \\
\hline $\begin{array}{l}\text { Almerich, G.; Suarez, J. M.; } \\
\text { Orellana, N. et al. }\end{array}$ & $\begin{array}{l}\text { Differences in the knowledge of the technological resources in } \\
\text { professors starting for gender, age and center type }\end{array}$ & 2005 & 25 \\
\hline $\begin{array}{l}\text { Cabrera, L.; Bethencourt, J.; } \\
\text { González, M.; et al. }\end{array}$ & $\begin{array}{l}\text { A retrospective transversal study of enlargement and college } \\
\text { dropout }\end{array}$ & 2006 & 19 \\
\hline $\begin{array}{l}\text { Rodríguez, C.; Pozo, T.; } \\
\text { Gutiérrez, J. }\end{array}$ & $\begin{array}{c}\text { Analytical triangulation, a resource for the validity of recurrent } \\
\text { survey studies and reply researches in Higher Education }\end{array}$ & 2006 & 18 \\
\hline $\begin{array}{l}\text { Ruiz-Corbella, M.; Galán, } \\
\text { A.; Diestro, A. }\end{array}$ & $\begin{array}{l}\text { Scientific journals on Education in Spain: evolution and } \\
\text { prospects for the future }\end{array}$ & 2014 & 17 \\
\hline $\begin{array}{l}\text { Gargallo, B.; Suarez- } \\
\text { Rodríguez, J.M.; Pérez- } \\
\text { Pérez, C. }\end{array}$ & $\begin{array}{l}\text { The CEVEAPEU Questionnaire. An instrument to assess the } \\
\text { learning strategies of university students }\end{array}$ & 2009 & 17 \\
\hline $\begin{array}{l}\text { Gargallo, B.; Almerich, G.; } \\
\text { Suarez-Rodríguez, J.M.; et } \\
\text { al. }\end{array}$ & $\begin{array}{l}\text { Learning strategies in excellent and average university students. } \\
\text { Their evolution over the first year of the career }\end{array}$ & 2012 & 16 \\
\hline $\begin{array}{l}\text { Fernández, J. E.; Fernández, } \\
\text { S.; Álvarez, A. et al. }\end{array}$ & $\begin{array}{c}\text { Academic Success and Student Satisfaction with University } \\
\text { Teaching }\end{array}$ & 2007 & 15 \\
\hline Brown, $\mathrm{S}$. & $\begin{array}{c}\text { International perspectives on assessment practice in Higher } \\
\text { Education }\end{array}$ & 2015 & 14 \\
\hline
\end{tabular}

We now turn our attention to analysis of the different indicators found in relation to the citing research works. This can aid us to uncover the way in which RELIEVE is perceived within its general specialty and within its closest neighboring research communities.
Firstly, we present the research areas (with categories classified according to WOS classifications) to which the journals and articles citing RELIEVE belong. Table 4 presents a cross-section of areas that may be representative of the different research settings to have shown interest in the content being published in RELIEVE. 
Table 4. Topic areas of the journals citing RELIEVE articles

\begin{tabular}{lcc}
\hline WOS categories & Citations & \% $(\mathbf{n}=\mathbf{5 9 9})$ \\
\hline EDUCATION EDUCATIONAL RESEARCH & 418 & 69.7 \\
PSYCHOLOGY EDUCATIONAL & 20 & 3.3 \\
SOCIAL SCIENCES INTERDISCIPLINARY & 19 & 3.1 \\
PSYCHOLOGY MULTIDISCIPLINARY & 17 & 2.8 \\
EDUCATION SCIENTIFIC DISCIPLINES & 15 & 2.5 \\
INFORMATION SCIENCE LIBRARY SCIENCE & 12 & 2.0 \\
COMMUNICATION & 11 & 1.8 \\
ENVIRONMENTAL SCIENCES & 9 & 1.5 \\
ENGINEERING MULTIDISCIPLINARY & 8 & 1.3 \\
PSYCHOLOGY APPLIED & 8 & 1.3 \\
BUSINESS & 7 & 1.1 \\
HOSPITALITY LEISURE SPORT TOURISM & 7 & 1.1 \\
\hline
\end{tabular}

As can be seen, the overriding majority $(70 \%)$ are journals from the category of EDUCATION AND EDUCATIONAL RESEARCH, with a much smaller percentage (3.3\%) coming from the second-placed category of PSYCHOLOGY EDUCATIONAL. Logically, given the core topics that RELIEVE is dedicated to covering as shown through the very titles of the emerging journals, namely, Revista Electrónica de Investigación y Evaluación
Educativa [Electronic Journal of Educational Research and Evaluation], the data produced adequately collaborate expected outcomes regarding journals. Outcomes to the contrary would have been concerning.

In this same sense, therefore, it is of great interest to analyze the journals themselves, of which the vast majority of the aforementioned category cite RELIEVE publications (Table $5)$.

Table 5. Journals citing RELIEVE publications

\begin{tabular}{lcc}
\hline Journals & Citations & \% $(\mathbf{n}=\mathbf{5 9 9})$ \\
\hline RELIEVE & 38 & 6.3 \\
RIE-REV INV EDUCATIVA & 22 & 3.6 \\
EDUCACION XX1 & 14 & 2.3 \\
PROFESORADO-REV CURR Y FOR PROF & 14 & 2.3 \\
REV DE EDUCACION & 14 & 2.3 \\
PIXEL BIT-REV MEDIOS Y EDUCACION & 13 & 2.1 \\
REV COMPLUTENSE DE EDUCACION & 12 & 2.0 \\
BORDON & 10 & 1.6 \\
EDUCATION IN THE KNOWLEDGE SOCIETY & 9 & 1.5 \\
EDULEARN PROCEEDINGS & 9 & 1.5 \\
REV IBE DE EDUCACION & 9 & 1.5 \\
REDU- REV DOCENCIA UNIVERSITARIA & 8 & 1.3 \\
REV ESPANOLA DE PEDAGOGIA & 8 & 1.3 \\
INTED PROCEEDINGS & 7 & 1.1 \\
RED-REV EDUCACION A DISTANCIA & 7 & 1.1 \\
REV ESP ORIENTACION Y PSICOPEDAGOGIA & 7 & 1.1 \\
CULTURA Y EDUCACION & 6 & 1.0 \\
EDUCATIO SIGLO XXI & 6 & 1.0 \\
ELEC JOURNAL RESEARCH EDU PSYCHOLOGY & 6 & 1.0 \\
ESTUDIOS SOBRE EDUCACION & 6 & 1.0 \\
ETIC NET & 6 & 1.0 \\
FRONTIERS IN PSYCHOLOGY & 6 & 1.0 \\
\hline
\end{tabular}


With regards to this indicator, data tends to reveal wide dispersion, even for high-impact journals. There is an almost never-ending list of citing journals, including the journal at the center of this review, with no clear nucleus emerging that accounts for a significant proportion of the citations. RELIEVE is not exempt from this pattern, with its main citing journal being RELIEVE itself, accounting for $6.3 \%$ (self-citations) of citations. The next prolific journal to cite RELIEVE is RIERevista de Investigación Educativa [Journal of Educational Research] with 3.6\%. These two journals are followed by a long list of Spanish journals with a decreasing percentage. From this, an interesting issue emerges in which we can observe that the list largely coincides with the journals cited by RELIEVE (Table 2, Figure 3). The main difference is that practically all of the foreign
JCR journals have disappeared from this second list. Although some English titles do appear in table 5 (with some of these being conferences), all of these are actually Spanish journals apart from FRONTIERS IN PSYCHOLOGY, which is a Swiss journal indexed in the JCR of the SSCI.

With regards to the authorship of the articles, table 6 presents the cross-section of countries and institutions who sign off on the work of the authors who most cite work published by RELIEVE. This list of countries is overwhelmingly headed by Spanish authors, with 453 of the 599 citations (75.6\%) being Spanish. This is followed, although a long way off, by authors from Latin America and the USA (accounting for between 6 and $3 \%$ ). Finally, minimal lip-service is paid by the rest of Europe (1\%), represented by Germany.

Table 6. Affiliated countries and institutions of the authors citing RELIEVE publications.

\begin{tabular}{lcclcc}
\hline Countries & Citations & $\begin{array}{c}\boldsymbol{\%}(\mathbf{n}= \\
\mathbf{5 9 9})\end{array}$ & Institutions & Citations & \% $(\mathbf{n}=\mathbf{5 9 9})$ \\
\hline SPAIN & 453 & 75.6 & UNIV VALENCIA & 56 & 9.3 \\
CHILE & 36 & 6.0 & UNIV GRANADA & 49 & 8.1 \\
MEXICO & 28 & 4.6 & UNIV SEVILLA & 33 & 5.5 \\
USA & 22 & 3.6 & UNIV BASQUE COU & 26 & 4.3 \\
COLOMBIA & 19 & 3.1 & UNIV BARCELONA & 24 & 4.0 \\
ARGENTINA & 18 & 3.0 & UNED & 18 & 3.0 \\
GERMANY & 6 & 1.0 & UCM & 17 & 2.8 \\
CUBA & 5 & 0.83 & UNIV MURCIA & 16 & 2.6 \\
ECUADOR & 5 & 0.83 & UNIV AUT MADRID & 15 & 2.5 \\
PR CHINA & 5 & 0.83 & UNIV HUELVA & 15 & 2.5 \\
& & & UNIV LA LAGUNA & 15 & 2.5 \\
\hline
\end{tabular}

The institutional affiliations of the citing authors strengthen data examination according to country. The list produced is made up of exclusively Spanish institutions, led by the universities of Valencia and Granada. On the other hand, these institutions are greatly invested in the publication of articles and scientific issues disseminated by RELIEVE, even though their official sponsoring organization is the AIDIPE (InterUniversity Association for Pedagogical Research). Although it was not deemed relevant to present the list of citing authors, it serves to name the first three: ChacónCuberos R. (Granada) who awards 11 citations, Almerich G. (Valencia) who awards 10 and Zurita-Ortega F. (Granada) with 9.

With regards to the document type and publishing language that characterize the publications citing RELIEVE (Table 7), there is almost complete predominance of original research articles, with these accounting for more than $90 \%$ of the citations. Further, the majority are published in the Spanish language $(67 \%)$. All of the above is in accordance with that seen in the citing 
journals which, as we have already seen, are largely Spanish. The emergence of $32 \%$ of English citing publications is not attributed to foreign journals but to Spanish journals. Indeed, Spanish journals are increasingly publishing in English as this is a useful dissemination strategy. RELIEVE itself also adopted this measure a number of years ago. With regards to the remaining citing publications, those belonging to other document types and languages make up an insignificant proportion of all citing publications.

Table 7. Document type and language of the publications citing RELIEVE publications

\begin{tabular}{lcclcc}
\hline Document type & Citations & $\mathbf{\%}(\mathbf{n}=\mathbf{5 9 9})$ & Language & Citations & \% $(\mathbf{n}=\mathbf{5 9 9})$ \\
\hline ARTICLES & 541 & 90.3 & SPANISH & 402 & 67.1 \\
CONFERENCES & 42 & 7.0 & ENGLISH & 192 & 32.0 \\
REVIEWS & 9 & 1.5 & CATALAN & 2 & 0.33 \\
BOOK CHAPTERS & 6 & 1.0 & PORTUGUES & 2 & 0.33 \\
& & & E & & \\
ONLINE ACCESS & 6 & 1.0 & GERMAN & 1 & 0.16 \\
EDITORIALS & 4 & 0.68 & RUSSIAN & 1 & 0.16 \\
BOOKS & 2 & 0.33 & & & \\
LETTERS & 1 & 0.16 & & & \\
\hline
\end{tabular}

Finally, we deemed it to be of interest to analyze, in as much detail as possible and as a function of the frequency of relevant author keywords listed in relation to the articles, the main research topics to have filled the pages of RELIEVE articles over the past 15 years. The map produced shows the terms that have been at the heart of researchers' interest (Figure 4).

Figure 4. Research themes considered by RELIEVE. 2005-2019

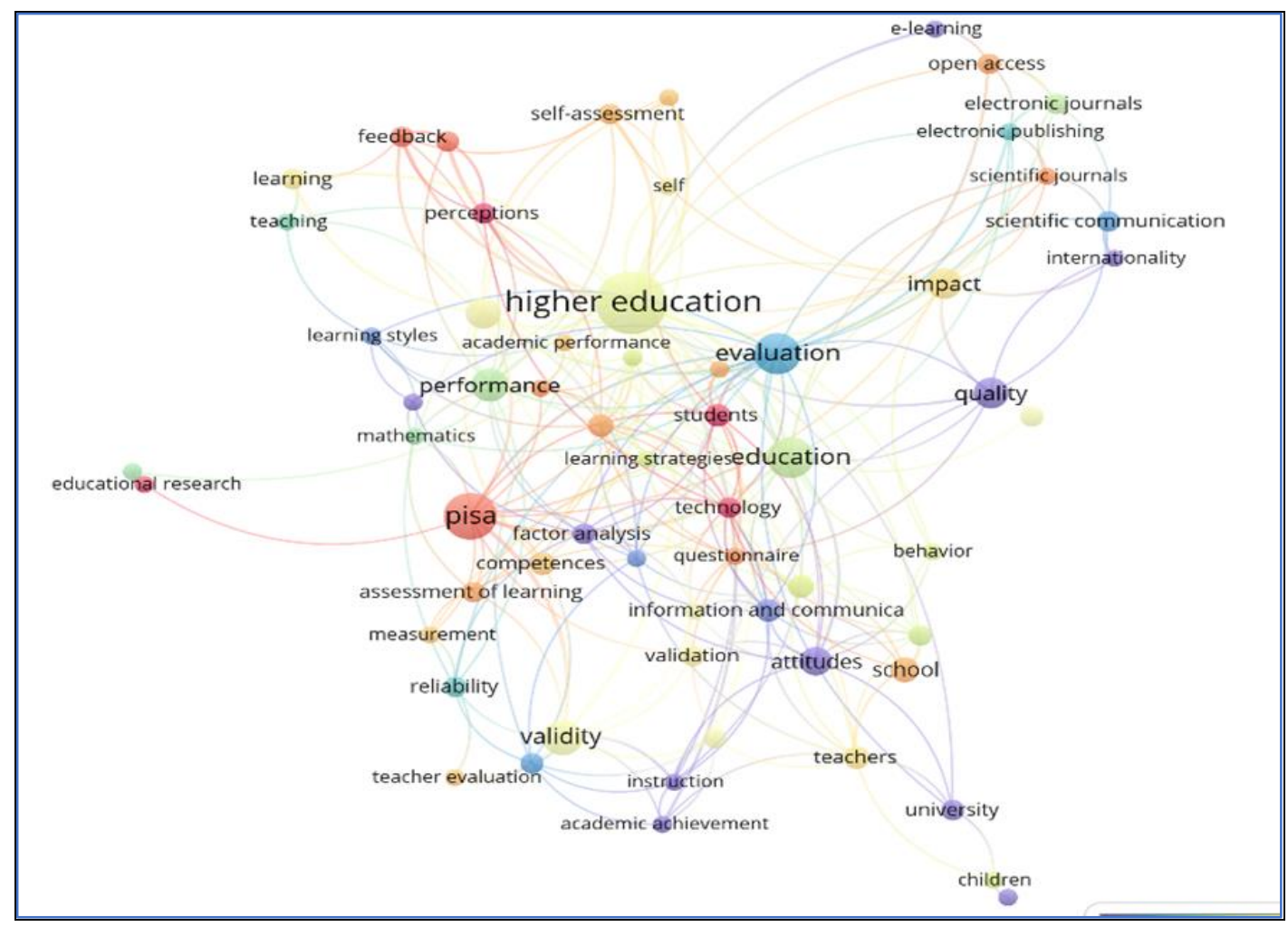


If we discard the themes that have little discriminative value in the context of interest to the present study such as Education or Learning, it is outlined that content relative to higher education and PISA [Ministry of Education and Vocational Training] carries the greatest weight. In relation to the central theme of higher education, terms relating to performance and evaluation also emerge within the same cluster. These terms show minor variations, for instance with learning evaluation and competencies, which also surround the other main content of the map which consists of studies concerning reports produced by that which is known as PISA. For the remaining themes, there are some other clearly distinguishable thematic groups which are far less important. For instance, to the upper right of the map, themes pertaining to scientific communication and scientific journals can be discerned.

\section{Discussion}

Data pertaining to the evolution of citations given by RELIEVE reveal an increase in the bibliographic weight of published works, in addition to a progressive improvement in the updating of references. This bibliographic update coincides with the far from negligible proportion (40\%) of citations given to foreign JCR journals. At the same time, this may be indicative of a sufficient consumption of international scientific literature by the authors of RELIEVE publications over the last 15 years.

In contrast, with regards to received citations, the absence of foreign authors and journals reveals that research published by RELIEVE is not highly diffused at an international level. The effect normally seen to take place when considering the publications of other Spanish authors from other disciplines is not seen to occur here. Specifically, when authors, mainly from the natural sciences or biomedicine, publish in international JCR journals, they tend to cite Spanish journals from their specialty. This promotes their international visibility (Porcel, Castellano, Valderrama, Aleixandre, and
Choren, 2003) (Ruiz-Pérez and RuizFresneda, 2019). Thus, perusal of the data indicates national isolation with regards to RELIEVE publications and only local consumption of its published research. Further, when we consider the institutions responsible for the publications, there is a tendency for the citations to come from other closely related settings. Whilst works are published for their scientific merit, it is understood that such citations largely come from members of the editorial and scientific committees of the journal itself.

This being said, such isolation is fairly common and makes up one of the pending subjects for Spanish journals to tackle. This is even true for those journals that already occupy lofty positions with regards to the JCR of WOS (Alexandre et al., 2004).

In relation to the themes considered by RELIEVE, it serves to question the scarcity of research content relating to education and evaluation at the primary and intermediate stages of the educational system. Indeed, presence of such content was far lower than that which would have been predicted. Terms such as primary, secondary education, children, teacher and instruction, appear very little or not at all in the map (Figure 2). This observation leads us to make the following reflection. We contrast the description of "excessively generic" coverage declared by RELIEVE: “...publishes articles on research and educational evaluation themes, which are understood in a broad sense", with the better definition given by WOS for the EDUCATION \& EDUCATIONAL RESEARCH categories. In this sense, the WOS states that "... [this] covers the entire educational spectrum, from the theoretical to the applied, from nursery to PhD...they include resources relating to pedagogy and methodology, the history of education, reading, curricular studies, educational policy and sociology, and the economy of education, alongside classroom computer use". This suggests or advises that guidelines be introduced to shape the RELIEVE statement. The aim of this is to diversify into 
other research theme profiles without, of course, over-extending the reach of educational research and evaluation.

It is still too soon to rate whether the inclusion of RELIEVE in the ESCI will be useful in overcoming national isolation and initiating international penetration by changing the dynamic of its processes with regards to the origin of citations. However, evolution of received citations indicates increasing progression which has been important in recent years (Figure 5).

Figure 5. Evolution of citations received by RELIEVE. 2007-2019

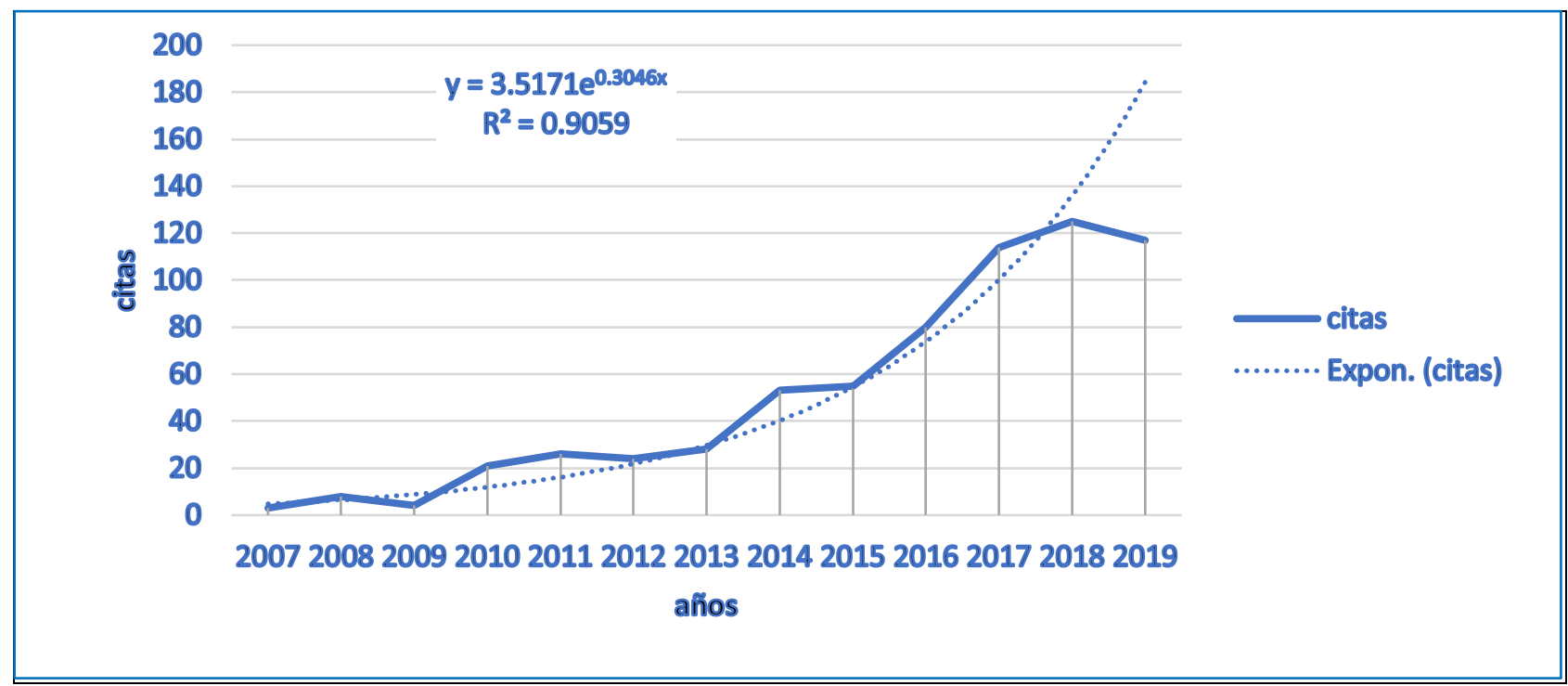

This evolution shows a tendency towards exponential growth, being close to $30 \%$ a year. During the 2015-2017 time-period, which corresponds to the start-up of ESCI databases, citations grew from 55 to 114 . This may reflect an early effect of ESCI, in addition to the growth of self-citations. We will have to wait and see whether the emergence of ESCI, which has undoubtedly improved international visibility, translates to some extent to international citations.

\section{References}

Aleixandre Benavent, R., Valderrama Zurián, J.C., Castellano Gómez, N., Miguel-Dasit, A., Simó Meléndez, R., \& Navarro Molina, C. (2004). Factor de impacto nacional e internacional de Revista Española de Cardiología. Rev Esp Cardiol, 57, 1241. https://doi.org/10.1016/S0300-8932(04)772681

CNEAI. (2019). Resolución de 12 de noviembre de 2019, de la Comisión Nacional Evaluadora de la Actividad Investigadora, por la que se publican los criterios específicos aprobados para cada uno de los campos de evaluación. http://www.aneca.es/Programas-de-

evaluacion/Evaluacion-de-

profesorado/CNEAI/Convocatoria-de-tramosde-investigacion-de-la-CNEAI-2019

ESCI. (2019). Master Journal List-Clarivate Analytics: Emerging Sources Citation Index [internet]. https://mjl.clarivate.com/searchresults

MJL. (2020). Master Journal List-Clarivate Analytics. https://mjl.clarivate.com/search$\underline{\text { results }}$

Porcel Torrens, A., Castellano Gómez, M., Valderrama Zurián, J.C., Aleixandre Benavent, R., \& Choren, S. (2003). Análisis de citas en la revista Adicciones. Adicciones, 15(4), 309319. https://doi.org/10.20882/adicciones.421

Ruiz-Pérez, R., \& Delgado López-Cózar, E., y Jiménez-Contreras, E. (2010). Principios y criterios utilizados en España por la Comisión Nacional Evaluadora de la Actividad Investigadora (CNEAI) para la valoración de las publicaciones científicas: 1989-2009. Psicothema, 22(4), 898-908. http://www.psicothema.com/psicothema.asp?id $=3818$ 
Ruiz-Pérez, R., \& Jiménez-Contreras, E. (2019). The Emerging Sources Citation Index and the internationalization of Spanish scientific journals, with special reference to Psychology journals. Psicothema, 31(4), 376-383. https://doi.org/10.7334/psicothema2019.59

Ruiz-Pérez, R., \& Ruiz-Fresneda, C. (2019). Integración internacional de la revista Ars Pharmaceutica. Ars Pharm(internet), 60(1), 47-57. https://doi.org/10.30827/ars.v60i1.8289

Testa, J. (2018). Journal Selection Process, actualizada Junio 2018. https://clarivate.com/essays/journal-selectionprocess/

Torres-Salinas, D., Bordons, M., Giménez Toledo, E., Delgado López-Cózar, E., JiménezContreras, E. \& Sanz-Casado, E. (2010).
Clasificación integrada de revistas científicas (CIRC): propuesta de categorización de las revistas en ciencias sociales y humanas. $E l$ profesional de la información, 19(6), 675-683. https://doi.org/10.3145/epi.2010.nov.15

WOS. (2018). Web of Science-Clarivate Analytics.

http://apps.webofknowledge.com/WOS_Gener alSearch_input.do;jsessionid=759622377A694 D8568C1AE646338EB19?product=WOS\&sea $\underline{\text { rch_mode }=\text { GeneralSearch } \& S I D=C 4 w n h Z t S 6 b}$ hU79brNak\&preferencesSaved

WOS. (2020). Web of Science Journal Evaluation Process and Selection Criteria. https://clarivate.com/webofsciencegroup/journ al-evaluation-process-and-selection-criteria/

\begin{tabular}{l} 
Authors / Autores \\
\hline Ruíz-Pérez, Rafael (rruiz@ugr.es) (D) 0000-0002-2656-1645 \\
Professor of Documentation at the School of Communication and Documentation of the University of Granada (Spain) \\
and member of the EC3 research group (Evaluation of Science and Scientific Communication). He is one of the \\
promoters of the Impact Indices of the Spanish Journals of Social, Legal and Human Sciences In-Recs / In-Recj / In- \\
Rech and DNA (National Directory of Authors). He is co-founder of the University of Granada Spin-off EC3metrics \\
$\begin{array}{l}\text { He has been advisor and member of program evaluation committees of the FECYT (Spanish Foundation for Science } \\
\text { and Technology), and has been part of the external reviewer panels in the ANECA accreditation processes in the field } \\
\text { of Social Sciences. }\end{array}$
\end{tabular}

Jiménez-Contreras, E. (evaristo@ugr.es) (iD 0000-0001-5668-7057

Professor of the Department of Information and Communication at the School of Communication and Documentation of the University of Granada (Spain) and responsible of the EC3 research group (Evaluation of Science and Scientific Communication). He is one of the promoters of the Impact Indices of the Spanish Journals of Social, Legal and Human Sciences In-Recs / In-Recj / In-Rech and DNA (National Directory of Authors).

$\mathrm{He}$ is co-founder of the University of Granada Spin-off EC3metrics

He is coordinator of the Doctoral Program in Social Sciences at the University of Granada and nowadays is a member of the ANECA accreditation comission in the field of Social Sciences.

\section{Revista ELectrónica de Investigación y EValuación Educativa E-Journal of Educational Research, Assessment and Evaluation [ISSN: 1134-4032]}

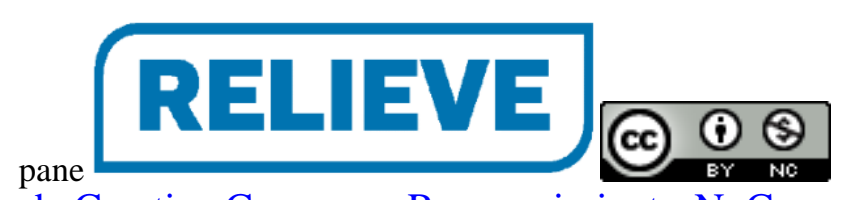

Esta obra tiene licencia de Creative Commons Reconocimiento-NoComercial 4.0 Internacional. This work is under a Creative Commons Attribution 4.0 International license. 